\title{
Menyingkap Rahasia di Balik Runtuhnya Lembaga Keuangan Mikro 'Bertopeng' Syariah
}

\author{
Agus Arifin*, Lilik Purwanti, Yeney Widya P \\ Program Magister Akuntansi, Fakultas Ekonomi dan Bisnis, Universitas Brawijaya, Malang \\ *arifintrainer1@gmail.com
}

\begin{abstract}
This study aims to explain the reasons behind the bankruptcy of BMT (Baitul Maal Wat Tanwil) PSU Malang with case study approach. The data are collected through documentation and interviews. The interviews are conducted on five informans namely informan $A, B, C, D$ and $E$. The results show that the bankruptcy of BMT PSU is caused by internal factors and external factors. Internal factors causing bankruptcy of BMT PSU are: unproductive fund management, bad credit (financing), fraud by employees, business loss, too high percentage of profit sharing, lack of good corporate governance $(G C G)$ and weak internal control. Externals include: lack of security guarantees on customers' funds, economic pressures, lack of supervision and guidance from relevant agencies, as well as the onslaught of stronger new competitors. The findings of this research related to the causes of the bankruptcy BMT PSU, is expected to be useful for practitioners and the government in preparing strategies for strengthening BMT in the future.
\end{abstract}

\section{Keywords: BMT (Baitul Maal Wat Tanwil), Collapse, Sharia Microfinance Institusions, Secret.}

\section{PENDAHULUAN}

Baitul Maal Wat Tamwil (BMT) merupakan lembaga keuangan mikro berbasis syariah yang saat ini mulai berkembang di tengah-tengah masyarakat. Menurut Djazuli \& Janwari (2002: 183), BMT merupakan balai usaha mandiri terpadu yang isinya berintikan bayt al-maal wat tamwil dengan kegiatan pengembangan usaha produktif dan investasi dalam meningkatkan kualitas kegiatan dan menunjang pembiayaan dalam kegiatan ekonomi. Lebih lanjut, menurut Wulandari et al. (2016), BMT memiliki tujuan memberikan pelayanan di bidang jasa keuangan bagi masyarakat, khususnya yang kurang mampu. BMT sendiri, pada dasarnya memiliki dua fungsi utama yaitu sebagai baitul maal dan batut tamwil (Wulandari \& Kassim, 2016). Selain menghimpun dana dari (c) (i) (?) masyarakat, BMT juga diperbolehkan menghimpun dan mengelola dana zakat, infaq, sedekah (ZIS) dan waqaf (Ahmed, 2002), sehingga BMT disebut menjalankan fungsi sebagai baitul maal.

Pada teknisnya, dana ZIS dari para dermawan tersebut akan dikelola dan disalurkan kepada pihak-pihak yang berhak menerimanya, sehingga keberadaan BMT dapat berkontribusi dalam pemberdayaan masyarakat dan pengentasan kemiskinan (Rahim \& Rahman, 2010). Baitul maal inilah yang oleh Juwaini \& Mintarti (2010) disebut sebagai penyokong utama BMT dalam menjalankan fungsi sosialnya, dengan memberikan pinjaman sukarela (qardul hasan) kepada orang-orang dari kalangan tidak mampu yang ingin mengembangkan usaha. Sementara itu, BMT sebagai baitut 
tamwil merupakan fungsi BMT yang lebih menekankan pada sisi bisnis, seperti penggalangan dana dengan akad wadi'ah atau titipan (Janwari, 2015:9) dan pengelolaan dana nasabah serta pembiayaan yang menguntungkan serta tetap sesuai dengan prinsip syariah.

Dua fungsi yang dijalankan oleh BMT, menjadikan BMT sebagai sebuah lembaga keuangan mikro berbasis syariah yang komplit, sehingga memiliki potensi besar untuk terus berkembang. Dua fungsi BMT tersebut (baitul maal dan baitut tamwil) awalnya juga dijalankan oleh BMT Perdana Surya Utama (PSU) Malang, sehingga dalam waktu yang cukup singkat BMT PSU berubah menjadi salah satu BMT terbesar di Kota Malang. Nasabah yang mencapai lebih dari 2000 orang dengan dana pihak ketiga yang terkumpul mencapai lebih dari 35 miliar, cukuplah menjadi bukti kejayaan BMT PSU saat itu. Tidak hanya itu, sejak tahun 2010 BMT PSU telah memiliki 10 (sepuluh) cabang di Kota Malang dengan total aset mencapai lebih dari 100 miliar, sehingga tidak heran jika beberapa pihak saat itu menyebut BMT PSU sebagai icon kemajuan industri keuangan syariah di Kota Malang.

Kejayaan BMT PSU seolah menjadi representasi pengelolaan BMT yang amanah dan profesional. Secara tidak tertulis, sistem pengelolaan BMT PSU seakan menjadi rujukan bagi BMT yang lainnya, namun kondisi tersebut rupanya tidak berlangsung lama. Berita kebangkrutan BMT PSU sangat mengejutkan karena BMT PSU yang selama ini terkesan sangat profesional dan berkembang pesat bisnisnya, tetapi tiba-tiba pada tahun 2015 dinyatakan bangkrut. Hal ini menimbulkan pertanyaan bagi banyak pihak tentang alasan di balik kebangkrutan BMT PSU. Untuk menjawab pertanyaan tersebut, tentunya perlu dilakukan penelitian menyeluruh agar dapat diketahui berbagai permasalahan yang dihadapi BMT PSU hingga terjadi kebangkrutan tersebut.

Penelitian ini menjadi sangat menarik untuk dilakukan, mengingat beberapa penelitian sebelumnya lebih banyak membahas permasalahan BMT secara parsial, misalnya Kusmiyati (2007) dan Anoraga (2015) yang membahas tentang permasalahan akad murabahah dalam BMT. Penelitian tersebut merupakan contoh dari sekian banyak penelitian yang membahas tentang sebagian sisi dari permasalahan sebuah BMT.

Berdasarkan fakta tersebut, diperlukan sebuah penelitian yang membahas permasalahan BMT secara holistik, hingga menyebabkan sebuah BMT mengalami kebangkrutan. Atas alasan itulah penelitian ini dilakukan, agar diperoleh jawaban yang jelas tentang alasan BMT PSU mengalami kebangkrutan. Hasil dari penelitian ini dapat menjadi pembelajaran bagi BMT lainnya untuk lebih mengevaluasi diri, sehingga musibah yang menimpa BMT PSU tidak terulang kembali.

\section{METODE}

Penelitian ini termasuk dalam jenis penelitian kualitatif dengan pendekatan studi kasus. Harling (2002) mengemukakan bahwa studi kasus merupakan sebuah penyelidikan yang dilakukan secara menyeluruh terhadap fenomena terkini yang terjadi secara alami. Menurut Yin (2013:1) menjelaskan bahwa penelitian studi kasus cocok digunakan untuk penelitian, dimana peneliti memiliki sedikit kontrol terhadap peritiwa yang diteliti, dan bilamana penelitian difokuskan pada fenomena-fenomena terkini (kontemporer).

Pendekatan studi kasus digunakan dalam penelitian ini, karena pembahasan lebih terfokus pada sebuah kasus kebangkrutan BMT PSU secara mendalam. Peneliti ingin mengupas secara lengkap tentang faktor-faktor yang menjadi penyebab kebangktutan BMT berdasarkan analisis data yang berasal dari para narasumber. Tidak hanya itu, jenis kasus yang masih tergolong kontemporer juga menjadikan pendekatan studi kasus sangat tepat digunakan dalam penelitian ini.

Metode pengumpulan data yang digunakan dalam penelitian ini adalah dokumentasi dan wawancara. Dokumentasi dilakukan dengan cara mengumpulkan dokumen-dokumen yang berkaitan dengan BMT PSU untuk selanjutnya dijadikan 
sebagai data pendukung pada proses penarikan kesimpulan. Wawancara dalam penelitian ini dilakukan terhadap lima orang informan. Pada penelitian ini, peneliti memutuskan untuk menyamarkan namanama para informan serta pihak-pihak lain yang peneliti sebutkan. Hal ini merupakan bagian dari etika peneliti untuk menjaga hak privasi para informan agar tidak berpotensi memunculkan masalah di kemudian hari. Adapun informan dalam penelitian ini adalah mantan pengurus yang diwakili oleh informan A, karyawan yang diwakili oleh informan B, nasabah BMT PSU yang diwakili oleh Informan C, Dinas Koperasi Kota Malang yang diwakili oleh Informan D dan praktisi BMT yang diwakili oleh informan $E$, sementara pihak lain yang dimaksud adalah non informan yang meliputi MD, AM (General Manager BMT PSU), AJ dan AI.

Teknik analisis data dalam penelitian ini diawali dengan melakukan reduksi data. Reduksi data dilakukan dengan melakukan penyaringan data yang terkumpul, baik berupa data rekaman wawancara maupun data yang berupa dokumen. Data yang berupa rekaman wawancara dengan para narasumber, terlebih dahulu ditranskripsikan ke dalam bentuk tulisan, kemudian dibaca ulang dan dilakukan perangkuman terhadap teks yang berisi jawaban narasumber. Jawaban yang dianggap penting dari setiap narasumber dikumpulkan menjadi satu berdasarkan tematema tertentu menjadi satu yang tertulis pada kertas dalam bentuk sebuah peta pikiran. Tema-tema yang dimaksud, akan dijelaskan pada bagian pembahasan.

Secara umum data penelitian ini dibagi menjadi dua yaitu data dokumentasi dan wawancara. Khusus data wawancara, masih terbagi menjadi data transkripsi wawancara nasabah, pengurus, karyawan, praktisi dan pemerintah.

\footnotetext{
Dokumentasi
}

Wawancara

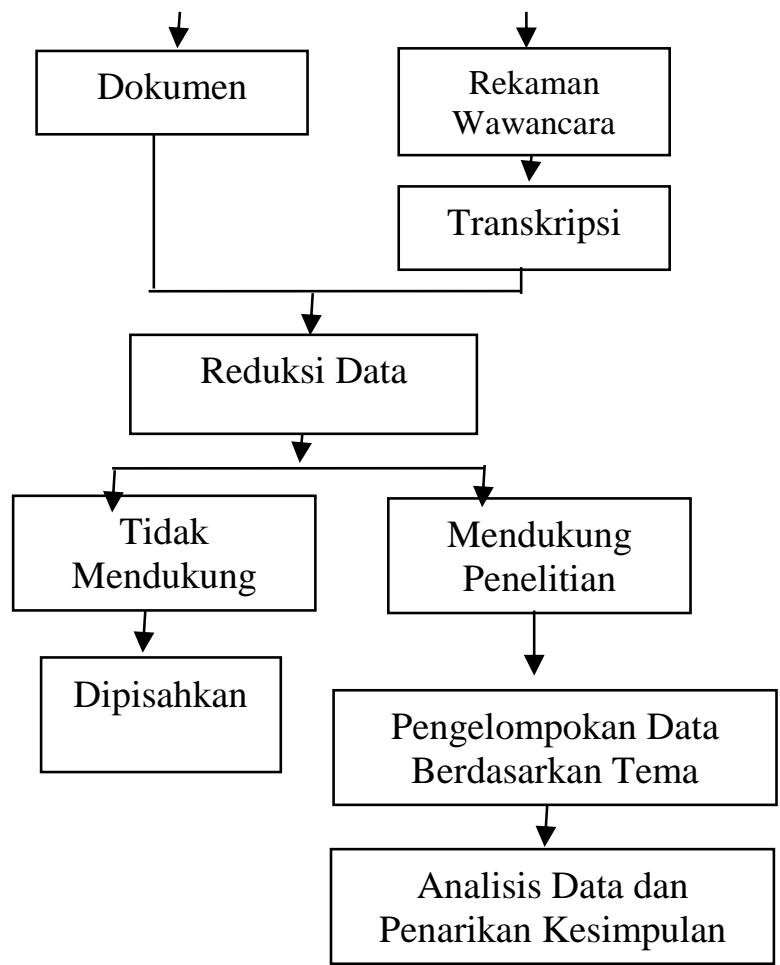

Gambar 1. Skema Proses Analisis Data

\section{HASIL DAN PEMBAHASAN Kronologi Kebangkrutan BMT PSU}

Tidak ada yang pernah menyangka, bahwa BMT PSU yang dahulunya begitu besar dan megah (sekitar tahun 2009 sampai dengan 2013), pada tahun 2018 hanya tinggal nama, akibat kebangkrutan yang menimpanya. BMT PSU yang dikenal profesional dan memiliki aset yang yang cukup besar, seakan menjadi simbol kebangkitan industri keuangan mikro syariah di Kota Malang. Pada saat itu, BMT PSU berhasil membuktikan bahwa ia mampu bersaing dengan banyak lembaga keuangan di Kota Malang yang telah lebih dahulu mapan. Terbukti bahwa BMT PSU telah memilki kantor pusat yang begitu megah di kawasan Jl. Soekarno Hatta. Selain itu, BMT PSU juga memiliki sepuluh kantor cabang yang tersebar di seluruh Kota Malang. Superioritas BMT PSU dalam industri keuangan mikro syariah di Kota Malang seakan sulit untuk dibendung kala itu. Bahkan BMT PSU sempat digadanggadang sebagai icon baru kejayaan lembaga keuangan mikro berbasis syariah di Kota Malang pada khususnya dan Jawa Timur pada umumnya. 
Visi dan misi yang jelas serta pengelolaan yang profesional menjadi kunci utama keberhasilan BMT PSU kala itu. Komitmen terhadap penerapan prinsipprinsip syari'ah serta pemberdayaan ekonomi umat, khususnya masyarakat kalangan menengah ke bawah menjadi spirit yang terus digaungkan oleh BMT PSU. Pada saat itu, rasanya tidak berlebihan jika peneliti menyebut BMT PSU sebagai the new rising star of BMT dikala itu. Apalagi BMT PSU secara kultural didukung oleh basis nasabah yang berasal ormas tertentu Kota Malang yang terkenal solid. Kedekatan kultur tersebut terbukti ampuh dan sangat berguna dalam menjaring nasabah. Terbukti bahwa Rumah Sakit Islam (RSI) ' $\mathrm{X}$ ' yang merupakan rumah sakit dari ormas tersebut berhasil dipengaruhi untuk menjalin kerjasama dengan BMT PSU. Hasilnya, seluruh karyawan RSI ' $\mathrm{X}$ ' bergabung menjadi nasabah BMT PSU. Tentu saja, bergabungnya seluruh karyawan RSI ' $\mathrm{X}$ ' menjadi nasabah, seakan menjadi suntikan moral dan finasial yang semakin menambah kekuatan BMT PSU.

Pada tahun 2015, BMT PSU dinyatakan bangkrut dan didemo oleh seluruh nasabah yang menuntut pengembalian dana mereka. Sungguh tidak ada yang menyangka sedikitpun bahwa BMT PSU yang tampak begitu perkasa dan dikelola secara profesional ternyata menyimpan bara api yang mampu membumi hanguskan semuanya tanpa tersisa. Para nasabah yang merasa ditipu, akhirnya melaporkan kasus tersebut ke Polres Kota Malang. Sejak saat itulah BMT PSU dinyatakan bangkrut/pailit dan dilarang beroperasi kembali. Gedungnya pun dikelilingi garis polisi, sebagai tanda bahwa sedang ada masalah dengan BMT PSU.

\section{Penyebab Kebangkrutan BMT PSU}

BMT PSU yang memiliki sejarah gemilang dalam industri keuangan mikro syariah di Jawa Timur, khususnya di Kota Malang membuat orang masih sulit percaya bahwa BMT tersebut kini telah lenyap dari peradaban. Hingga saat ini pun, masih banyak pihak yang bertanya-tanya, mengapa BMT PSU dapat mengalami kebangkrutan?
Padahal secara prospek di masa depan, dengan nasabah yang mencapai lebih dari 2000 orang dan dengan kantor cabang yang sudah mencapai sepuluh unit, BMT PSU berpotensi menjadi raksasa lembaga keuangan mikro berbasis syariah di Jawa Timur khususnya dan di Indonesia pada umumnya, namun ternyata takdir berkehendak lain. Petualangan BMT PSU di kancah industri keuangan syariah berakhir dengan tragis. BMT PSU dinyatakan bangkrut dan gagal melakukan pengembalian dana nasabah. Lebih suramnya lagi, 2 tahun pasca kebangkrutan BMT PSU, AH selaku GM BMT PSU dinyatakan meninggal dunia akibat serangan jantung. Penelitian ini mencoba untuk menginvestigasi kasus tersebut agar dapat diketahui secara akurat tentang alasan bangkrutnya BMT PSU.

Berdasarkan wawancara dengan keenam narasumber peneliti menemukan beberapa point utama yang menjadi sebab kebangkrutan BMT PSU. Beberapa point utama yang menjadi penyebab kebangkrutan BMT PSU tersebut, peneliti mengelompokkannya menjadi faktor internal dan faktor eksternal. Faktor internal lebih pada penyebab yang berkaitan dengan internal manajemen BMT PSU, sedangkan faktor eksternal lebih fokus pada penyebab yang berasal dari luar BMT PSU atau dengan kata lain BMT PSU tidak memiliki kuasa untuk mengontrol faktor tersebut. Selanjutnya peneliti menyebutkan dan menguraikan masing masing dari faktorfaktor (internal dan eksternal) tersebut secara jelas dan lengkap.

\section{Faktor Internal \\ Manajemen Dana Tidak Produktif}

BMT merupakan lembaga keuangan yang nyawanya adalah sektor riil, sehingga sangat tidak mungkin BMT dipisahkan dari sektor tersebut. Sebuah BMT akan sehat jika uang nasabah yang terkumpul digunakan semaksimal mungkin untuk pembiayaan yang berkaitan dengan sektor riil. Menurut Ulum (2014), salah satu strategi untuk meningkatkan produktifitas dana nasabah BMT adalah dengan cara menentukan terlebih dahulu segmen pembiayaan, kemudian 
direncanakan treatment untuk setiap segmen tersebut untuk memastikan bahwa pembiayaan dapat menghasilkan keuntungan seperti yang telah direncanakan.

Bagaimanapun kondisinya, uang nasabah harus diputar agar lebih produktif, sehingga BMT dapat memperoleh keuntungan dari usaha yang dijalankannya dan mampu memberikan bagi hasil secara rutin kepada para nasabah. Hal inilah yang menurut Ulum (2014), fungsi intermediasi dari BMT perlu dimaksimalkan untuk menjembatani pihak-pihak yang memiliki modal dengan pihak-pihak yang membutuhkan modal dalam rangka menjalankan sebuah bisnis. Ironisnya, BMT PSU yang terjadi pada BMT PSU justru sebaliknya. Ironisnya, BMT PSU tidak mampu mengelola dana para nasabah secara produktif. Padahal, sebuah BMT semestinya terus melakukan pembiayaan agar dapat menambah modal finansial baik bagi BMT sendiri maupun bagi pelaku usaha mikro (Prasetiawati \& Darma, 2016).

Fakta menunjukkan bahwa BMT PSU telah gagal mengemban amanah dari para nasabah. Pembelian tanah di J1. SoekarnoHatta yang menelan biaya 12,5 miliar membuat operasional bisnis BMT PSU menyebabkan BMT PSU terpuruk dan dinyatakan bangkrut.

Bagi sebuah lembaga keuangan mikro, uang sejumlah 12,5 miliar adalah jumlah uang yang sangat besar. Jika uang sejumlah itu tidak diinvestasikan ke sektor bisnis yang produktif, maka hal tersebut akan dapat mempengaruhi tingkat kesehatan kas BMT, sementara di sisi lain, setiap bulannya BMT PSU harus membayar bagi hasil kepada para nasabah yang jumlahnya juga tidak sedikit. Lalu dari mana BMT PSU mendapatkan uang untuk membayar dana bagi hasil nasabahnya? Jawabannya adalah dari berhutang kepada banyak pihak, mulai dari BMT ' $Y$ ', Koperasi Syariah ' $H$ ', RSI ' $\mathrm{X}$ ' Kota Lamongan sampai pada hutang secara personal kepada banyak orang yang dikenal oleh General Manajer (GM) BMT PSU.

Berdasarkan investigasi yang peneliti lakukan pada lingkungan sekitar rumah $\mathrm{AH}$ yang merupakan GM BMT PSU, ternyata diperoleh fakta bahwa rumahnya saat ini sudah disegel oleh pihak Koperasi Syariah 'H'. Hal itu dikarenakan AH tidak mampu membayar hutang kepada Koperasi Syariah ' $\mathrm{H}$ ' yang telah jatuh tempo. Adapun hutang BMT PSU yang diwakili oleh AH kepada pihak Koperasi Syariah ' $\mathrm{H}$ ' jumlahnya mencapai 2 miliar. Jumlah tersebut belum termasuk bagi hasilnya yang harus dibayar. Selain itu, peneliti juga menemukan fakta mengejutkan lainnya. Menurut pengakuan petugas keamanan (satpam) yang bertugas di kompleks perumahan tempat $\mathrm{AH}$ tinggal, mayoritas tetangga di sekitar rumah tersebut juga memiliki piutang terhadap $\mathrm{AH}$ secara personal. Salah seorang tetangga yang enggan disebutkan namanya juga mengaku memberikan pinjaman sebesar 60 juta kepada AH untuk keperluan membayar gaji karyawan BMT PSU dan hingga kini pinjaman tersebut belum juga dikembalikan, sementara $\mathrm{AH}$ sendiri telah meninggal dunia. Hal ini semakin memperjelas gambaran bahwa cash flow BMT PSU saat itu sudah sedemikian kritisnya.

Permasalahan seputar tidak sehatnya cash flow BMT PSU juga diungkapkan oleh informan A yang merupakan ketua pengurus BMT PSU. Menurutnya, salah satu penyebab kebangkrutan BMT PSU adalah tidak sehatnya cash flow perusahaan dan pengelolaan yang tidak profesional. Berikut adalah kutipan pernyataan selengkapnya:

"Menurut saya memang manajemennya yang amburadul. Manajemennya yang tidak tertib. Alurnya tidak jelas, cash flownya, output (pengeluaran) operasional itu lebih besar daripada income yang diperoleh perusahaan. Jadi, 'besar pasak daripada tiang'. Intinya cashflownya yang tidak sehat"

Secara terpisah informan C memperkuat pernyataan informan A tentang tidak sehatnya cash flow BMT PSU yang terkait dengan pembelian tanah di $\mathrm{Jl}$. Soekarno-Hatta, hingga menimbulkan 
masalah fatal. Berikut adalah pernyataan informan $\mathrm{C}$ selengkapnya:

" Uang di BMT PSU ini amburadul mas, tidak sesuai lagi dengan koperasi. Seharusnya uang itu diputar untuk kegiatan permodalan bisnis, tapi ini malah diivestasikan ke pembelian tanah di Soekarno-Hatta. Itulah awal mula penyebab BMT PSU bangkrut, sedangkan almarhum AH ini menjanjikan kalau invest di situ, almarhum menjanjikan bagi hasil ada yang $1,25 \%$ per bulan, ada juga yang $1,5 \%$ per bulan, sementara uang tidak berputar. Inilah awal permasalahannya mas, karena uang tidak berputar, maka uang nasabah yang disimpan kesedot untuk membayar bagi hasil ke nasabah."

Pernyataan informan $\mathrm{C}$ di atas semakin mempertegas, bahwa sejak pembelian tanah tersebut, praktis bisnis BMT di sektor riil menjadi terganggu karena masalah minimnya ketersediaan kas, sementara BMT PSU harus terus membayar belanja rutin seperti gaji pegawai dan bagi hasil untuk nasabah.

\section{Piutang Tanpa Jaminan (Collateral)}

Wawancara yang peneliti lakukan menunjukkan temuan adanya piutang yang dimiliki oleh BMT PSU, namun tanpa jaminan apapun, bahkan ada pula yang tidak tercatat secara tertulis dalam pembukuan. Hal ini sangat bertentangan dengan prinsip akuntansi dan prinsip-prinsip pemberian kredit yang salah satunya adalah collateral (Kasmir, 2012: 101-105). Selain itu, apa yang dilakukan oleh BMT PSU dengan memberikan pinjaman tanpa jaminan dan tanpa pencatatan, juga sangat bertentangan dengan firman Allah di dalam QS. Albaqarah 282 yang berbunyi:

"Hai orang-orang yang beriman, apabila kamu bermu'amalah tidak secara tunai untuk waktu yang ditentukan, hendaklah kamu menuliskannya. Dan hendaklah seorang penulis diantara kamu menuliskannya dengan benar. Dan janganlah penulis enggan menuliskannya sebagaimana Allah mengajarkannya, maka hendaklah ia menulis, dan hendaklah orang yang berhutang itu mendektekan (apa yang ditulis itu), dan hendaklah ia bertakwa kepada Allah Tuhannya, dan janganlah ia mengurangi sedikitpun dari hutangnya. (QS. Al-Baqarah: 282).

Ayat di atas menunjukkan betapa Islam sangat menjunjung prinsip kehati-hatian dalam hal hutang piutang, sehingga setiap orang yang melakukan transaksi tidak secara tunai diwajibkan untuk mencatat dengan sedetail mungkin. Hal itulah yang sepertinya luput dari perhatian pihak manajemen BMT PSU, sehingga muncullah hutang piutang yang tidak tercatat dan bahkan tanpa jaminan. Masalah tersebut menjadi semakin rumit karena piutang tersebut melibatkan jumlah uang yang cukup besar serta melibatkan orang-orang-orang dekat (keluarga) dari $\mathrm{AH}$. Saat dikonfirmasi tentang hal tersebut, informan B mengatakan:

"Jadi di BMT itu ada yang orang pinjam tanpa jaminan, artinya hanya personal guarantee dan jumlahnya juga banyak. Salah satu diantaranya Pak MD itu pinjam miliaran, tanpa ada jaminan dan tanpa tercatat. Data yang tercatat saja pinjaman Pak MD itu 4M, tetapi teman-teman memperkirakan lebih dari itu. Permasalahannya adalah tidak ada catatannya, karena yang tahu hanya kakak dan adik. Itu permasalahannya. Bahkan menurut saya, termasuk yang menghancurkan BMT itu adalah si MD ini. Menurut teman-teman, MD inilah yang maling dan mafia.

Apa yang diungkapkan oleh informan B semakin diperkuat oleh dokumen akta pernyataan (kesaksian) yang ditanda tangani secara bersama-sama oleh mantan karyawan BMT PSU dengan di bawah sumpah (di bawah Al-Qur'an). Akta tersebut menjelaskan secara rinci besarnya uang yang dipinjam oleh MD kepada BMT PSU per-Desember 2009 mencapai Rp4.022.484.000 (empat miliar dua puluh dua juta empat ratus delapan puluh 
empat ribu rupiah), dengan beban margin atau kewajiban bagi hasil sebesar Rp2.840.150.000 (dua miliar delapan ratus empat puluh juta seratus lima puluh ribu rupiah). Bahkan, data per Desember 2014, disebutkan dalam akta tersebut bahwa pinjaman dan kewajiban bagi hasil saudara MD telah mencapai Rp20.117.232.791 (dua puluh miliar seratus tujuh belas juta dua ratus tiga puluh dua ribu tujuh ratus sembilan puluh satu rupiah), dengan beban margin hutang yang dihitung setara $24 \%$ per tahun atau $2 \%$ per bulan.

Fakta di atas tentu saja sangat mengejutkan. Bagaimana bisa BMT meminjamkan uang sebesar itu dengan tanpa jaminan? Lalu bagaimana bisa BMT yang notabene lembaga keuangan berprinsip syariah, menjalankan praktik pinjam meminjam dengan sistem ribawi seperti itu. Besarnya jumlah uang nasabah yang dipinjam pihak ketiga tanpa adanya jaminan dan tidak juga tertagih, praktis menyebakan cashflow BMT PSU menjadi sangat tidak sehat, sehingga untuk membiayai operasionalnya BMT PSU hanya bergantung pada hutang dan funding. Funding dilakukan baik kepada nasabah lama maupun kepada calon nasabah baru yang masih dapat 'dibodohi'. Jika dihitung secara matematis, anggaplah hutang MD dibulatkan menjadi 4 miliar rupiah, maka dengan asumsi kewajiban bagi hasil per bulan berkisar 1-1,5\%, maka BMT PSU harus membayar kewajiban bagi hasil kepada nasabah sebesar 40 juta s.d 60 juta sebulan atau 480 juta s.d 720 juta per tahun. Kewajiban untuk membayar kewajiban bagi hasil sebesar itu, sungguh tidak mengherankan jika akhirnya BMT PSU hancur dan dinyatakan bangkrut.

\section{Kredit (Pembiayaan) Macet}

Menurut Qodin (2015), terdapat setidaknya tiga faktor yang menyebabkan terjadinya kredit macet di BMT yaitu: karakter anggota, kebangkrutan usaha dari anggota, dan musibah. Khusus untuk BMT PSU, pada dasarnya kredit (pembiayaan) tersebut masih dapat ditagih, karena sebagian besar macetnya kredit dikarenakan minimnya tenaga penagih, sehingga seringkali kredit tersebut tidak terkelola dengan baik. Sebagai jaminan dari kredit macet tersebut, adalah beberapa surat berharga (seperti: BPKB motor dan mobil, sertifikat tanah dan rumah) yang saat ini diamankan oleh tim penyelamat dana nasabah, menjadi satu-satunya harapan agar kredit yang macet dapat ditagih kembali. Kredit macet seolah menjadi "momok" yang menakutkan bagi BMT PSU. Hal ini terkonfirmasi, saat peneliti bertanya tentang penyebab dari kebangkrutan BMT PSU selain faktor kepemimpinan, tanpa berfikir panjang informan B menjawab:

"Uang tidak berputar, termasuk pembiayaan yang macet itu salah satu sebab diantara sebab-sebab lain. Sekarang ini sedang berusaha ditagih, kalau tidak salah catatannya ada $9 \mathrm{M}$ an. Itu sekarang tugasnya tim penyelamat uang nasabah."

Berdasarkan pernyataan di atas, peneliti kemudian mengkonfirmasi tentang jumlah kredit macet (pembiayaan) BMT PSU tersebut kepada informan $\mathrm{C}$ untuk membuktikan kebenaran informasi tersebut. Informan $\mathrm{C}$ menyebutkan data yang sama dengan yang disampaikan oleh informan B. Uang sebesar 9 miliar tersebut adalah uang nasabah seluruhnya yang tentunya BMT PSU memiliki kewajiban untuk membayar kewajiban bagi hasil kepada nasabah setiap bulannya.

Kewajiban bagi hasil BMT PSU kepada para nasabah, sama seperti yang peneliti telah uraikan sebelumnya yaitu $1-1,5 \%$ per bulan. Artinya, untuk dana kredit macet yang mencapai 9 miliar, BMT PSU harus membayar bagi hasil kepada para nasabah sebesar 90-135 juta perbulan atau 1,08-1,62 miliar pertahun. Sungguh jumlah yang luar biasa, maka tak heran jika BMT PSU yang dulunya begitu superior, seketika menjadi pesakitan dan berujung pada kebangkrutan. Kredit macet yang terjadi di BMT PSU sebenarnya tidak hanya disebabkan oleh faktor eksternal, melainkan juga faktor internal. Hal ini dikarenakan jumlah sumber daya manusia (SDM) BMT PSU yang diplot 
untuk bertugas melakukan penagihan sangat minim, bahkan hampir tidak ada, sehingga BMT PSU tidak mampu menjalankan penagihan kepada debitur secara rutin. BMT PSU lebih banyak fokus mengalokasikan SDM untuk kegiatan funding nasabah baru, sehingga menyebabkan ketidak seimbangan kinerja. Akibatnya banyak debitur yang tidak terkontrol dan tidak melunasi pinjaman secara tepat waktu, atau bahkan tidak mengembalikan sama sekali.

\section{Fraud oleh Karyawan BMT PSU}

Menurut Blanque (2003), fraud adalah pemindahan standar hukum sebagai konsekuensi dari upaya untuk menghindari standar tersebut. Hal ini berarti, tindakan fraud berusaha memanipulasi aturan atau standar yang dianggap memberatkan atau merugikan para pelaku fraud. Mereka akan berusaha mengganti aturan tersebut dengan aturan-aturan atau standar yang menguntungkannya. Sedikit berbeda dengan Blanque (2003), definisi fraud menurut Albrecht (2012) Jauh lebih kompleks yaitu:

"Fraud is a generic term, and embraces all the multifarious means which human ingenuity can devise, which are resorted to by one individual, to get an advantage over another by false representations. No definite and invariable rule can be laid down as a general proposition in defining fraud, as it includes surprise, trickery, cunning and unfair ways by which another is cheated. The only boundaries defining it are those which limit human knavery".

Berdasarkan definisi di atas, Albrecht (2012) meyakini bahwa fraud tidak hanya sebatas pada memanipulasi aturan, melainkan juga pada perbuatan licik lainnya yang bertujuan untuk menguntungkan dirinya sendiri. Albrecht (2012) juga menegaskan bahwa antitesis dari fraud adalah kejujuran, sehingga jika seseorang ingin mengetahui sebuah tindakan termasuk dalam fraud atau tidak sangatlah mudah. Seseorang tersebut hanya perlu mengetahui batasan-batasan antara kejujuran dan ketidakjujuran. Jika sebuah perbuatan sudah melewati batas kejujuran (melenceng dari kejujuran), maka tindakan tersebut adalah tindakan fraud. Agar seseorang dapat terhindar dari berbuat fraud secara tidak sengaja, maka seseorang tersebut haruslah memiliki pemahaman yang memadai tentang fraud. Watson (2003) menuntut hal yang lebih kompleks, yaitu seseorang diharuskan memiliki pemahaman fraud dan budaya demi menghindari terjadinya tindakan fraud.

Hasil wawancara menunjukkan bahwa sebelum terjadinya kebangkrutan, di BMT PSU sering juga terjadi penggelapan dana oleh karyawan. Menurut Dorminey, Fleming, Kranacher \& Riley (2012), terdapat tiga komponen yang merupakan cara seseorang melakukan fraud yaitu pencurian, penyembunyian, dan konversi. Penggelapan dana yang dilakukan oleh karyawan BMT PSU tersebut masuk dalam kategori fraud dengan pencurian. Tentunya, dana yang dicuri oleh karyawan merupakan dana nasabah, sehingga BMT PSU harus menanggung kerugian yang tidak sedikit jumlahnya akibat tindakan keji para karyawan tersebut.

Pada akhirnya peneliti menganggap 'wajar' jika kemudian BMT PSU mengalami kebangkrutan, karena BMT PSU mendapatkan banyak masalah, mulai dari pembelian tanah yang terletak di Jl. SoekarnoHatta yang menguras dana 12,5 miliar, piutang tanpa jaminan senilai 4 miliar, kredit (pembiayaan) macet senilai 9 miliar, dan yang terakhir adalah penggelapan dana oleh karyawan BMT PSU sendiri. Hal ini merupakan potensi terjadinya fraud di BMT PSU. Saat peneliti menanyakan kepada informan B perihal dugaan fraud oleh karyawan, informan B menjawab:

"Ada sebelumnya, ada. Saya jujur bilang ada. Tapi orangnya sudah dikeluarkan. Jadi karyawan yang detik-detik terakhir masih tetap bertahan adalah karyawankaryawan yang jujur, fokus dan kerja beneran. Justru yang keluar-keluar itu bermasalah dengan keuangan BMT, bahkan penyalahgunaan. Contoh, misalnya kalau ada nasabah mau menyimpan 
deposito, dibuatkan akad sendiri sama dia. Saya tidak ceritakan siapa orangnya, tapi yang pasti ada beberapa orang. Akhirnya ketahuan..."

Berdasarkan keterangan di atas, jelas terlihat bahwa telah terjadi penggelapan dana oleh karyawan BMT PSU hingga beberapa kali yang menyebabkan kerugian secara materi dalam jumlah besar. Pada akhirnya tidak dapat dibantah lagi bahwa penggelapan dana yang dilakukan oleh karyawan merupakan salah satu pemicu tidak sehatnya cash flow perusahaan yang akhirnya berujung pada bangkrutnya BMT PSU.

\section{Kerugian Bisnis}

Kerugian bisnis yang seringkali menimpa BMT PSU lebih banyak disebabkan oleh faktor internal manajemen yang kurang cermat dan hati-hati dalam menjalankan bisnis. Sebagai contoh untuk bisnis BMT PSU yang paling jelas terlihat adalah pendirian mini market dengan nama Surya Mart di J1. Soekarno-Hatta merupakan sebuah langkah ceroboh yang fatal. Mengapa demikian? Karena secara analisis dari berbagai aspek, pendirian "Surya Mart" sungguh sangat tidak menguntungkan. Dari aspek lokasi misalnya, maka lokasi dimana mini market "Surya Mart" berdiri tersebut sangat tidak strategis. Hal ini dikarenakan lokasi tersebut terkenal sebagai langganan macet, sehingga orang cenderung malas untuk sekedar mampir. Aspek yang lainnya adalah dari segi persaingan. Pada jalur sepanjang Jl. Soekarno-Hatta telah banyak berdiri mini market yang jauh lebih mapan dengan merk branding yang lebih kuat, serta modal yang lebih besar. Berdasarkan dua analisis aspek tersebut, maka sudah dapat ditebak bagaimana nasib mini market "Surya Mart" BMT PSU. Tidak lebih dari satu tahun, mini market "Surya Mart" terpaksa ditutup karena rugi, karena sepinya pelanggan yang berbelanja di sana.

Akibat perencanaan yang kurang matang dan cermat, sekali lagi BMT PSU harus menanggung kerugian yang tidak sedikit jumlahnya. Katakanlah modal yang digunakan untuk memulai usaha mini market "Surya Mart" tersebut sebesar 300 juta rupiah, maka kurang lebih satu tahun uang 300 juta tersebut tidak berputar alias tidak produktif dan bahkan habis akibat kerugian, sementara di sisi lain, ada kewajiban BMT PSU untuk membayar kewajiban bagi hasil kepada para nasabah. Hitungan sederhananya, jika nisbah bagi hasil $12 \%-18 \%$ per tahun dan dengan modal yang terpakai sebesar Rp300.000.000,00, maka BMT PSU harus membayar bagi hasil kepada nasabah sebesar Rp36.000.000,00 s.d Rp54.000.000,- per tahun. Jumlah tersebut tentunya harus ditambahkan dengan modal 300 juta yang juga habis terpakai dan tidak kembali. Hal inilah yang semakin lama, semakin menggerogoti kemampuan BMT dalam mengelola cash flow, sehingga apa yang terjadi pada BMT PSU saat ini, merupakan akumulasi dari beberapa kecerobohan di masa lalu.

\section{Terlalu Tingginya Persentase Bagi Hasil}

Salah satu hal yang menjadikan BMT PSU begitu banyak diminati oleh masyarakat adalah karena persentase bagi hasil yang dijanjikan sangatlah besar. Persentase bagi hasil tersebut dihitung dari besarnya modal yang disetor oleh nasabah dan bersifat flat antara $1-1,5 \%$ per bulannya atau $12-15 \%$ per tahun. Nilai tersebut sangat jauh di atas BI rate yang hanya berkisar antara $4-6 \%$ per tahunnya. Pada April 2018 saja, BI rate hanya mencapai 4,25\% per tahun (Bank Indonesia, 2018). Tentunya dengan bagi hasil sebesar itu, tidaklah mengherankan jika BMT PSU mampu menjaring nasabah yang cukup banyak, karena masyarakat merasa diuntungkan dengan menginvestasikan uangnya ke BMT PSU karena mereka diprediksi akan memperoleh keuntungan yang besar secara pasti setiap bulannya.

Untuk menyiasati besarnya persentase bagi hasil yang diberikan, BMT PSU menetapkan persentase bagi hasil untuk pembiayaan yang juga jauh lebih besar yaitu sekitar $2 \%$ per bulan, sehingga BMT PSU secara hitungan matematis masih memperoleh keuntungan (margin) yang 
berasal dari selisih antara bagi hasil yang diterima dari kegiatan pembiayaan dengan bagi hasil yang harus dibayarkan kepada nasabah. Terdapat selisih $0,5-1 \%$ per bulan disana. Sungguh keuntungan yang sangat menggiurkan, karena berdasarkan informasi dari Gatot, dana nasabah yang ada di BMT PSU mencapai 35 miliar, artinya jika 30 miliar saja dari dana tersebut dijalankan untuk kegiatan pembiayaan secara maksimal, maka BMT PSU akan mendapatkan keuntungan bagi hasil sebesar 600 juta per bulan, atau 7,2 miliar per tahun. Jumlah tersebut hanyalah asumsi jika pembiayaan mencapai 30 miliar, jika ternyata pembiayaan lebih daripada itu, maka hasilnya pun akan jauh lebih besar.

Ironisnya, dengan potensi keuntungan yang sangat besar tersebut, BMT PSU malah mengalami kebangkrutan. Isu inefisiensi menjadi salah ditengarai menjadi penyebab munculnya permasalahan keuangan di BMT PSU. Menurut Ghofur (2007), secara umum terdapat dua jenis efisiensi yaitu efisiensi teknik dan ekonomi. Pada kasus BMT PSU ini, efisiensi ekonomi menjadi masalah yang sangat krusial, karena menurut Yuliningrum (2012), sebagian besar BMT mengalami masalah dalam hal efisiensi, khususnya efisiensi ekonomi. Pernyataan tersebut secara jelas memiliki korelasi dengan kondisi yang terjadi di BMT PSU yaitu pengeluaran yang lebih besar daripada pemasukan.

Sekedar informasi bahwa untuk jumlah uang nasabah sebesar 35 miliar, BMT PSU harus membayar bagi hasil sebesar 350 juta s.d 525 juta per bulan atau 700 juta s.d 1,5 miliar per tahun. Melihat besarnya beban bagi hasil yang harus ditanggung oleh BMT PSU tersebut, maka sangat wajar jika pada akhirnya BMT PSU tidak mampu mempertahankan eksistensinya di industri keuangan mikro syariah dan dinyatakan bangkrut. Hal ini sejalan dengan apa yang diungkapkan Chowdhury (2006) bahwa lembaga keuangan mikro syariah dengan sistem profit and low sharing memberikan terlalu banyak ketidakpastian, karena cenderung berbiaya besar.

\section{Tidak Adanya Kemauan Menerapkan Good Corporate Governance (GCG)}

Good Corporate Governance

merupakan sistem yang mengatur hak dan kewajiban pemegang saham, pengurus, pihak kreditur, pemerintah, karyawan serta para pemegang kepentingan internal dan eksternal lainnya (FCGI, 2001). Sedikit berbeda, Zarkasyi (2008) menjelaskan bahwa GCG merupakan struktur yang dibentuk oleh stakeholder, pemegang saham, komisaris, dan manajer dalam menyusun tujuan perusahaan serta sebagai sarana untuk mencapai tujuan tersebut. Solomon (2007), menegaskan bahwa pada prinsipnya GCG erusaha untuk menyeimbangkan dan mengontrol perusahaan baik secara internal dan eksternal untuk menjamin akuntabilitas perusahaan terhadap seluruh stakeholder serta pertan kepada seluruh stakeholder serta pertanggungjawaban sosial perusahaan terhadap lingkungan tempat beroperasinya perusahaan. Lebih jauh Steger, Urich \& Amann (2008:4), menjelaskan bahwa GCG terbangun atas dasar struktur yang jelas dan mengedepankan akuntabilitas, tanggung jawab dan transparansi perusahaan dalam mendefinisikan berbagai aturan manajemen. KNKG (2006), menyebutkan secara lebih lengkap tentang azas dari GCG meliputi: transparansi, akuntabilitas, responsibilitas, independensi, kewajaran serta kesetaraan.

Jika diperhatikan secara seksama, maka terdapat perbedaan yang sangat jauh antara azas yang menjadi dasar penerapan GCG dengan apa yang terjadi pada BMT PSU. Berdasarkan temuan peneliti di lapangan, tidak ada satupun azas dalam GCG yang dipraktekkan oleh BMT PSU. Ada semacam kesengajaan dari pihak GM BMT PSU untuk tidak menerapkan GCG demi tujuan tertentu yang pastinya dianggap menguntungkan bagi dirinya. Setidaknya terdapat tiga kondisi di BMT PSU yang menjadi bukti tidak diterapkannya GCG di BMT PSU yaitu: kepemimpinan one man show, tidak adanya transparansi keuangan dan tidak adanya SOP yang jelas.

Faktor kepemimpinan juga memiliki andil besar dalam memperparah situasi yang 
terjadi di BMT PSU, hingga akhirnya terjadi kebangkrutan. Kepememimpinan $\mathrm{AH}$ yang cenderung one man show, semakin menciptakan suasana kerja di BMT PSU yang tidak nyaman. Padahal hal yang berbeda tentunya akan terjadi jika $\mathrm{AH}$ mengusung gaya kepemimpinan partisipatif, karena menurut Huang, Iun, Liu \& Gong (2009) gaya kepemimpinan, khususnya partisipatif akan mampu meningkatkan kinerja karyawan. Pendapat senada juga diungkapkan oleh Soeyitno (2013) yang juga meyakini bahwa gaya kepemimpinan partisipatif berepengaruh secara positif terhadap kinerja karyawan. Sepertinya, kedua pendapat tersebut tidak berlaku bagi $\mathrm{AH}$, karena baginya karyawan hanya dijadikan sebagai pion untuk menghadapi para nasabah tanpa tahu kemana masa depan BMT PSU akan di bawa. Saat dimintai keterangan mengenai hal ini (kepemimpinan one man show dari $\mathrm{AH}$ ), informan $\mathrm{B}$ pun dengan lugas mengatakan:

\begin{abstract}
"Saya lihat Pak AH itu single fighter masalahnya, one man show, dan itu kita ingatkan dengan seluruh teman-teman. Sekaliber Pak AH itu seharusnya ada tim khusus, tim kecil yang bisa mengawal, mengantar sehingga perjalanan BMT ini dapat berjalan dengan baik gitu kan ya. Terkontrol, laporannya transparan, itu mulai tahun itu (2015) tak delok koq mulai ngene iki (saya lihat koq mulai begini). Bisa juga karena kondisi keuangannya tidak jelas, sehingga kekuatan one man show nya semakin terasa, dan teman-teman semakin ee..bisa saya katakan agak bingung...."
\end{abstract}

Selain model kepemimpinan $\mathrm{AH}$ yang cenderung one man show, juga tidak adanya tranparansi dari pimpinan kepada seluruh karyawan dan nasabah, sehingga karyawan dan nasabah tidak dapat mengetahui secara pasti bagaimana kondisi keuangan BMT PSU yang sesungguhnya. Tertutupnya $\mathrm{AH}$, menyebabkan arus informasi menjadi terhambat, sehingga pengurus dan karyawan tidak tahu apa yang harus dilakukan. Kondisi ini telah menyebabkan terjadinya ketidakseimbangan informasi yang dimiliki oleh GM para pengurus dan karyawan. Kondisi itulah yang menurut Scott (2006) disebut dengan istilah asimetri informasi. Menurut Wijayanto, Rahmawati \& Suparno (2007), asimetri informasi akan muncul saat manajer lebih mengetahui informasi internal dan prospek perusahaan dimasa yang akan datang dibandingkan pemegang saham dan stakeholder lainnya, termasuk regulator. Yustiningarti \& Asyik (2017) kemudian menyimpulkan bahwa kondisi asimetri informasi akan cenderung memunculkan moral hazard bagi siapapun pihak yang memiliki informasi lebih banyak. Tampaknya kondisi demikian (asimetri informasi) juga terjadi pada BMT PSU.

Pada kasus BMT PSU, asimetri informasi terjadi antara sang GM dengan para karyawan dan nasabah. AH selaku GM terlalu banyak memiliki informasi, sementara pihak lainnya (pengurus, karyawan dan nasabah) sangat terbatas informasi. Akibatnya, pengurus dan karyawan tidak dapat melakukan langkah antisipasi terhadap kemungkinan BMT PSU mengalami krisis keuangan. Perilaku GM BMT PSU yang tidak transparan juga dianggap sebagai salah satu biang keladi kehancuran BMT PSU. Hal ini diperkuat oleh informan $\mathrm{C}$ dengan mengatakan:

"Menurut saya penyebab BMT PSU ini bangkrut, karena manajemen yang tidak terbuka/transparan dalam mengelola keuangan, sehingga apa pun yang selama ini dia (Pak AH) lakukan telah menyimpang dari aturan yang ada.“

Tidak hanya informan $\mathrm{B}$ dan $\mathrm{C}$ yang mengatakan bahwa tidak transparan, informan A,D,E dan F pun mengakui bahwa BMT PSU mengalami kebangkrutan akibat tidak transparannya pihak $\mathrm{AH}$ selaku GM BMT PSU dalam keuangan. Hal ini sesuai dengan yang diungkapkan Tjondro \& Wilopo (2011) bahwa transparansi yang merupakan bagian dari azas dalam Good Corporate Governance (GCG) dapat berpengaruh terhadap sustainabilitas sebuah perusahaan. 
Transparansi inilah yang tidak dimiliki oleh BMT PSU, sehingga sangat wajar jika akhirnya BMT PSU terjerumus dalam kebangkrutan.

Pengelolaan BMT PSU yang cenderung tidak transparan, sebenarnya tidak dapat dipisahkan dari ketiadaan Standard Operating Procedure (SOP). Setiap perusahaan yang dikelola secara profesional pastilah memiliki SOP yang jelas, sehingga setiap langkah yang dijalankan haruslah sesuai aturan yang ada di dalam perusahaan. Hal ini menjadi sangat penting untuk diperhatikan, agar tidak ada oknum karyawan yang melakukan tindakan, baik secara disengaja ataupun tidak disengaja dapat menimbulkan kerugian bagi perusahaan. Menurut Tambunan (2013), SOP merupakan pedoman yang berisi prosedur-prosedur operasional standar yang ada di dalam suatu organisasi atau perusahaan untuk memastikan bahwa setiap keputusan yang diambil serta langkah-langkah yang dilaksanakan telah berjalan secara efektif, konsisten, standar, dan sistematis. Hadiwiyono \& Panjaitan (2013) menambahkan bahwa SOP memiliki manfaat sebagai dokumen referensi bagi seseorang tentang bagaimana cara menyelesaikan suatu pekerjaan atau proses. Intinya, keberadaan SOP akan mempermudah proses operasional sebuah perusahaan, karena segalanya telah memiliki aturan pelaksanaan yang rapi.

Pada dasarnya, belum adanya SOP yang diterapkan secara konsisten menyebabkan BMT PSU mengalami banyak masalah dalam proses operasionalnya. Tidak adanya SOP, membuktikan bahwa manajemen BMT PSU belum menerapkan GCG yang menurut KNKG (2006), memiliki lima prinsip transparansi, akuntabilitas, responsibilitas ,independensi dan kewajaran serta kesetaraan. Berdasarkan lima prinsip tersebut kemudian Purwanto \& Mustamu (2013), menjelaskan bahwa penerapan SOP yang baik merupakan bagian dari penerapan prinsip akuntabilitas, sehingga jika sebuah perusahaan telah memiliki dan menerapkan SOP yang baik, maka perusahaan tersebut telah melaksanakan GCG. Fakta yang terjadi pada BMT PSU justru sebaliknya yaitu tidak ada SOP, sehingga prinsip akuntabilitas sudah jelas tidak terpenuhi dan semakin jauh dari kriteria yang dituntut oleh GCG.

\section{Lemahnya Internal Control}

Internal control menjadi salah satu isu menarik dalam pembahasan seputar kebangkrutan BMT PSU. Lemahnya Internal control, terbukti menjadi salah satu penyebab bangkrutnya BMT PSU. Hal ini semakin memperkuat bukti bahwa internal control, memegang peranan penting bagi keberlanjutan bisnis perusahaan. Secara umum, menurut Mulyadi (2002: 180), terdapat tiga tujuan dari pengendalian internal yaitu: keandalan informasi keuangan, kepatuhan terhadap hukum dan peraturan yang berlaku serta efektivitas dan efisiensi operasi.

Lemahnya sistem internal control menyebabkan ketiga tujuan pengendalian internal sulit untuk diwujudkan, sehingga menimbulkan gejolak dalam tubuh BMT PSU yang berimbas pada menurunnya kepercayaan nasabah secara drastis. Lemahnya sistem internal control BMT PSU, terungkap berdasarkan penuturan beberapa informan yang menyebutkan tentang beberapa faktor penyebab kebangkrutan BMT PSU. Menilik pada pernyataan para informan tersebut, peneliti mencatat beberapa kondisi yang menunjukkan lemahnya internal control di BMT PSU, adalah dimatikannya peran pengurus dan tidak adanya Dewan Pengawas Syariah (DPS).

Pada stuktur BMT yang memiliki badan hukum koperasi, maka posisi pengurus merupakan posisi yang tertinggi setelah Rapat Anggota Tahunan (RAT), sedangkan GM adalah bagian dari karyawan yang secara struktural berada di bawah pengurus dan bertanggung jawab kepada pengurus, sementara pengurus bertanggung jawab langsung kepada RAT. Pengurus memiliki tugas memimpin organisasi dan usaha koperasi (BMT PSU), sesuai yang tercantum dalam Anggaran Dasar BMT PSU pada pasal 27 ayat 1 (Lihat lampiran 4). Tidak hanya itu, peran pengurus koperasi secara jelas juga telah diatur dalam pasal 30 ayat 1 UU No. 25 
tahun 1992 tentang perkoperasian (Ikopin, 2015). Faktanya, peran pengurus di BMT PSU sangatlah minim atau dapat dikatakan sengaja dimatikan agar sang GM dapat dengan leluasa mengambil keputusan sesuai keinginannnya. Dimatikannya fungsi pengurus ini juga diungkapkan oleh informan A yang mengatakan:

"Sebenarnya kalau pengurus itu kan decision maker ya, tapi di BMT PSU ini beda. Pengurus bertanggung jawab kepada rapat anggota, itu idealnya, kemudian jika pengurus memiliki kesibukan sendirisendiri, untuk mengelola koperasi, pengurus mengangkat manajer dan manajernya adalah Pak $\mathrm{AH}$, tetapi perlakuan di BMT PSU ini lain, karena dalam hal ini yang dominan justru Pak AH, sehingga tugas dan fungsi pengurus kurang berjalan dengan bagus. Seluruh kebijakan dikendalikan oleh Pak AH. Kewenangan yang harusnya menjadi milik pengurus, diambil alih oleh Pak AH, sehingga pengurus tidak punya peran dan kurang diperankan. Kondisi itu berjalan bertahuntahun sejak awal BMT PSU berdiri."

Pernyataan informan A tentang tidak berjalannya peran dan fungsi pengurus dalam struktur organisasi BMT PSU juga diakui oleh informan B dengan mengatakan:

"Jangankan karyawan, lha wong pengurusnya sendiri saja nggak bisa, nggak sanggup bahkan terjadi semacam apa, mengundurkan diri karena nggak iso dikandani (tidak bisa dikasih tahu), tidak bisa digurui. Ketika dievaluasi nggak mau terus terang dan sebagainya, itu padahal pengurus lho, apalagi kita yang dibawah dia"

Pernyataan kedua informan tersebut telah mengkonfirmasi secara lugas bahwa kontrol terhadap AH sama sekali tidak ada, sehingga $\mathrm{AH}$ dapat mengambil tindakan sesuka hatinya yang pada akhirnya berakibat fatal, yaitu kebangkrutan BMT PSU.
Selain peran pengurus yang dimatikan, buruknya pengawasan juga terlihat dari tidak berjalannya fungsi DPS. Menurut Wardiwiyono (2012), berdasarkan penelitiannya terhadap BMT-BMT yang ada di Yogyakarta, menunjukkan bahwa penerapan otorisasi dan konsultasi oleh pihak BMT kepada DPS sangatlah rendah. Hasil penelitian tersebut setidaknya dapat menjadi rujukan untuk mengetahui sejauh mana BMT memfungsikan DPS. Jika mengacu pada penelitian Wardiwiyono (2012), maka tidak mengherankan jika pada akhirnya ditemukan beberapa BMT yang secara operasional bisnis tidak sepenuhnya menjalankan prinsipprinsip syariah dan bahkan, pengelolaannya hampir sulit diidentifikasi unsur syariahnya karena para pelakunya tidak menjiwai prinsip-prinsip dan tujuan syariah. Hal ini adalah akibat dari peran dari DPS yang kurang maksimal atau bahkan terkesan dimatikan fungsinya.

Jika berkaca pada DPS yang ada di bank syariah, maka menurut Mardian (2015), jikalaupun DPS ada, maka independensinya pun masih dipertanyakan, mengingat DPS merupakan bagian dari struktur internal yang menerima gaji dari bank syariah tersebut. Kondisi yang terjadi pada DPS BMT tidak jauh berbeda dengan DPS di bank syariah, sehingga membutuhkan formulasi khusus agar mampu menunjukkan independensi dan ketegasan dalam menegakkan prinsip-prinsip syariah di BMT.

Saat peneliti mengkonfirmasi kepada salah satu informan B tentang kepastian adanya DPS di dalam struktur organisasi BMT PSU, Anas menjawab:

"Ada memang DPS, tapi proses pengangkatannya saya tidak tahu. Memang dimasukkan nama Pak AJ, ada Pak AI masuk, tapi awal-awalnya berjalan, setelah itu tidak berjalan. Akhirnya yang nangani Pak AH semua. Bisa anggota DPS asal comot, karena untuk kepentingan apa saya juga tidak tahu, yang jelas Pak AJ pernah diundang dalam rangka apa ya, pembukaan pencairan tabungan apa gitu saya lupa." 
Setelah peneliti mengkonfirmasi langsung nama salah satu anggota DPS (AJ) yang disebutkan di atas, ternyata memang benar bahwa AJ tidak pernah menjadi anggota DPS BMT PSU Kota Malang. Artinya, anggota DPS yang ada di BMT PSU hanyalah fiktif semata. Hal inilah yang menjadikan DPS tidak berfungsi sebagaimana mestinya.

Tidak berperannya DPS secara maksimal, menyebabkan proses operasional BMT PSU yang dipimpin oleh AH seakan tidak memiliki arah. Ruh Islam semakin lama semakin pudar, karena lebih banyak menonjolkan sisi bisnisnya. Akibatnya praktik pengelolaan keuangan BMT PSU pun telah menyimpang jauh dari prinsip-prinsip syariah. Terbukti bahwa sistem bagi hasil yang diterapkan di BMT PSU menganut sistem flat dan dihitung dari besarnya modal. Padahal praktik seperti itu mengandung unsur riba.

Riba pada intinya merupakan pengambilan tambahan dari harta pokok atau modal secara batil (Nawatmi, 2010). Riba secara eksplisit telah difirmankan Allah dalam QS. Ali Imran :130 dan Al-Baqarah: 275-281. Menurut Ghofur (2016), selain AlQur'an yang telah menjelaskan secara eksplisit, pelarangan riba juga dikarenakan terdapat relevansi ke sektor riil. Perekonomian yang berbasis riba, biasanya akan cenderung menegasikan sektor riil dan cenderung kapitalis, yang pada akhirnya akan menimbulkan kesenjangan ekonomi luar biasa, sehingga jurang pemisah antara si kaya dan si miskin semakin besar.

Tidak hanya sistem bagi hasil yang menyimpang dari prinsip-prinsip syariah, namun juga hal-hal lain yang menyebabkan kebangkrutan BMT PSU seperti kredit macet, pinjaman dengan kwajiban bagi hasil yang tinggi dan pinjaman tanpa jaminan, serta masalah transparansi pengelolaan keuangan BMT PSU akan dapat dicegah jika DPS benar-benar ada dan difungsikan di BMT PSU. Keberadaan DPS yang berjalan sesuai fungsinya akan mampu mengarahkan dan mengawasi manajemen agar tetap berjalan dalam bingkai prinsip-prinsip syariah. DPS akan mampu memberikan nasihat, masukan, pertimbangan dan arahan kepada manajemen tentang berbagai macam bisnis yang halal dan haram serta memastikan bahwa setiap langkah dan keputusan bisnis yang diambil oleh manajemen terhindar dari unsur riba.

\section{Faktor Eksternal : \\ Minimnya Jaminan Keamanan Atas Dana Nasabah}

Salah satu penyebab kebangkrutan BMT PSU adalah ketidakmampuan BMT dalam menjaga kepercayaan nasabah. Reputasi BMT PSU di mata para nasabah telah berada di titik terendah. Hal ini sesuai dengan yang diungkapkan Ganesan (1994) bahwa reputasi perusahaan yang baik akan menciptakan kepercayaan dan hubungan kemitraan yang baik. Pendapat tersebut juga diakui oleh Saxton (1997), yang menyatakan bahwa kepercayaan menjadi faktor penting dalam hubungan kemitraan antara nasabah dengan lembaga keuangan. Lebih lanjut, Wardayati (2011) menambahkan bahwa kepercayaan nasabah dapat diwujudkan salah satunya melalui transparansi. Kenyataannya, justru transparansi itulah yang tidak ada dalam diri BMT PSU, sehingga menimbulkan ketidakpastian atas keamanan dana nasabah.

Ketidakpastian atas jaminan keamananan dana nasabah, sebenarnya dapat diatasi jika BMT memiliki lembaga penjamin simpanan layaknya bank. Jaminan dari lembaga itulah yang akan membentuk kepercayaan nasabah terhadap BMT, karena bagaimanapun juga para nasabah tidak ingin mengambil risiko untuk menyimpan uangnya di sebuah lembaga keuangan syariah, jika tidak mendapatkan jaminan keamanan.

Intinya adalah nasabah membutuhkan keamanan atas uang yang mereka simpan dan BMT berkewajiban untuk memenuhinya. Jika BMT tidak mampu memenuhinya, maka taruhannya adalah kepercayaan nasabah yang akan semakin menurun. Belum adanya lembaga penjamin simpanan (LPS) khusus untuk BMT, menjadi salah satu kendala terbesar bagi BMT untuk menjaring nasabah yang potensial. Selain itu, ketiadaan LPS untuk BMT juga menjadikan posisi BMT semakin terjepit karena harus bersaing dengan 
bank yang juga mulai membidik sektor mikro. Sungguh sebuah kondisi yang tidak menguntungkan bagi BMT, karena secara posisi di mata masyarakat, mereka (bank) jauh lebih kuat mengingat bank-bank tersebut telah dijamin oleh LPS, sehingga keamanan dana nasabah jauh lebih terjamin.

\section{Tekanan Ekonomi}

Tekanan ekonomi yang begitu besar menjadi salah satu faktor eksternal penyebab kebangkrutan BMT PSU. Tekanan ekonomi akan membuat pihak yang tertekan cenderung frustasi dan melakukan tindakan di luar kewajaran. Tindakannya seringkali negatif dan berakibat fatal bagi keberlangsungan bisnis sebuah perusahaan. Pihak-pihak yang terus mendapatkan tekanan ekonomi, akan berusaha menghalalkan segala cara demi menghilangkan tekanan tersebut. Hal inilah yang kemudian oleh Dorminey et al. (2012) dikatakan bahwa tekanan ekonomi menjadi salah satu penyebab munculnya fraud.

Berbicara tentang penyebab bangkrutnya BMT PSU, maka tidak akan terlepas dari faktor tekanan ekonomi. Tekanan ekonomi tersebut lebih banyak dihadapi oleh GM yang menjadi pengendali utama roda bisnis BMT PSU. Fakta dimana GM berani meminjam uang kepada BMT ' $\mathrm{Y}$ ' dengan kewajiban bagi hasil yang sangat tinggi yakni $3 \%$ per bulan sangat jauh dari nilai-nilai syariah atau cenderung mengandung unsur riba, karena sejalan dengan yang dikemukakan oleh Nawatmi (2010) bahwa riba adalah pengambilan tambahan dari harta pokok atau modal secara bathil.

Indikasi jeratan hutang dengan sistem riba BMT PSU sangat jelas mengingat jumlah hutang kepada pihak BMT ' $\mathrm{Y}$ ' yang semula hanya berjumlah sekitar 6 miliar, setelah ditambah bagi hasil, seketika berubah menjadi 13 miliar. Menurut informan B, pihak BMT PSU dikenakan bagi hasil 3\% setiap bulannya, yang dihitung dari besarnya pinjaman. Informan $\mathrm{C}$ menambahkan bahwa hingga kini jumlah hutang BMT PSU kepada pihak ketiga lengkap dengan bagi hasilnya mencapai lebih dari 20 miliar. Jumlah tersebut belum termasuk hutang di tempat lain. Kondisi ini, oleh Dormeney et al. (2012) disebut sebagai tekanan yang pada akhirnya mendorong seseorang sanggup melakukan segala cara untuk memenuhi tuntutan tersebut, termasuk dengan melakukan fraud.

\section{Minimnya Pengawasan dan Pembinaan dari Instansi Terkait}

Menurut Schermerhorn (2002:12), pengawasan merupakan yang dilakukan dalam rangka meningkatkan kinerja dan pengambilan tindakan yang telah ditetapkan oleh perusahaan. Lebih lanjut, Stoner, Freeman \& Gilbert (1995:114) menyimpulkan bahwa yang dimaksud dengan pengawasan adalah proses yang dilakukan untuk memastikan bahwa aktivitas telah terlaksana sesuai perencanaan. Berdasarkan dua definisi tersebut jelas bahwa tujuan dari sebuah pengawasan adalah terlaksananya rencana pelaksanaan yang telah ditetapkan agar terjadi peningkatan kinerja perusahaan.

Minimnya monitoring, evaluasi dan pembinaan dari pihak Dinas Koperasi dan Usaha Mikro Kota Malang, menjadi salah satu faktor yang menyebabkan kehancuran BMT PSU. Minimnya monitoring, evaluasi dan pembinaan tersebut menjadikan permasalahan yang dihadapi oleh BMT PSU tidak terdeteksi dan terkesan dibiarkan, sehingga menjadi semakin kompleks dan sulit untuk diselesaikan. Hal tersebut tidak akan terjadi jika sejak awal Dinas Koperasi dan Usaha Mikro Kota Malang berperan aktif dan secara rutin mengadakan pengawasan dan pembinaan, khususnya terhadap BMT PSU, sehingga permasalahan-permasalahan yang muncul dapat segera dikonsultasikan dan dicarikan jalan keluarnya.

Saat peneliti mengkonfirmasi kepada informan $\mathrm{B}$, terkait minimnya pengawasan dan pembinaan terhadap BMT PSU oleh Dinas Koperasi dan Usaha Mikro Kota Malang, ia membenarkan hal tersebut, dengan mengatakan:

"Menurut saya, kelemahannya dinas koperasi itu tidak mengarahkan, tidak membimbing dan tidak mengevaluasi. 
Padahal mereka punya anggaran. Seharusnya kan misalnya setiap 3 bulan sekali seluruh koperasi wilayah kecamatan ini berapa totalnya, dikumpulkan, diaudit misalnya. Ditanya apa kendalanya, apa permasalahannya, dibina. Itu yang menurut saya tidak dilakukan sampai detik ini. Termasuk koperasi BMT (Baitul Magfirah) yang kami kelola ini, itupun tidak ada pembinaan. Mereka pernah datang kesini hanya tanya sebentar, foto, laporan, tapi tidak ada pembinaan. Nah, kelemahan ketika BMT PSU dulu tidak ada pembinaan secara intens, secara serius, hanya laporan tiap tahun diundang, makan-makan, dikasih 'amplop' pulang. Itu yang saya tahu. Kita nyangoni (ngasih uang) kita ini dan kalau saya lihat, nampaknya itu terjadi sampai sekarang. Padahal dananya ada untuk pembinaan, pengawasan dan lain-lain."

Hal senada juga diungkapkan oleh informan A yang juga pernah menjabat sebagai mantan Bidang Organisasi dan Kelembagaan Dinas Koperasi dan Usaha Mikro Kota Malang. Saat peneliti bertanya tentang peran Dinas Koperasi dan Usaha Mikro Kota Malang Kota Malang dalam proses pengawasan dan pembinaan untuk meminimalisir terjadinya kasus seperti BMT PSU, informan A menjawab:

"Menurut saya saat ini di dinas koperasi tidak ada orang orang yang benar-benar memiliki pengetahuan yang mendalam tentang koperasi. Beda dengan zaman ibu dulu. Kalau sekarang, bagaimana mau melakukan pengawasan dan pembinaan, jika yang diawasi dan yang dibina lebih pintar daripada pengawas dan pembinanya?. Pejabat koperasi seharusnya melalui sertifikasi yang ketat setelah mengalami pembinaan berjenjang, mulai dari pembinaan dasar perkoperasian, pengetahuan tentang pengawasan, pembinaan, training of trainer (TOT), pendidikan manajemen keuangan dan lainlain."
Minimnya kualitas sumberdaya pengawas dan pembina koperasi juga diakui oleh informan ' $E$ ' selaku pakar dan praktisi BMT. Ia berusaha memberikan pemahaman tentang kondisi Dinas Koperasi dan Usaha Mikro di setiap daerah khususnya di Kota Malang serta memberikan kritik membangun terhadap Dinas Koperasi dan Usaha Mikro dengan mengatakan:

"Kita tahu bahwa di Kementerian Koperasi ini personilnya kurang. Apalagi di tingkat kabupaten kota itu pejabat karirnya sudah habis rata-rata itu, yang berkarir betul di bidang perkoperasian, sehingga tahu betul seluk-beluknya koperasi. Termasuk kasusnya BMT PSU itu, salah satu faktornya karena pembinanya ya sudah ndak karu-karuan (tidak jelas). Ada yang dari dinas pasar, dinas kesehatan, bahkan kepala dinasnya saja dari seorang dokter. Terakhir dari satpol PP, jadi kan kacau ini. Lha orang yang di bawah itu, tinggal satu dua saja, sehingga ya memang repot itu."

Permasalahan terkait minimnya pengawasan dan pembinaan oleh dinas koperasi, diakui oleh informan ' $D$ ' selaku perwakilan dari pihak Dinas Koperasi dan Usaha Mikro Kota Malang, Informan 'D' berdalih bahwa minimnya pengawasan dan pembinaan yang dilakukan oleh dinas koperasi karena faktor sumber daya manusia (SDM) yang sangat minim, sementara jumlah koperasi yang harus diawasi sangat banyak. Hal ini tercermin dalam kutipan pernyataan informan ' $\mathrm{D}$ ' di bawah ini:

"Kami mengakui bahwa sejauh ini pengawasan dan pembinaan sudah dilakukan, namun masih belum maksimal, karena bagaimana ya mas, jumlah SDM kita sangat sedikit, hanya tiga orang jumlahnya dan yang harus diawasi banyak sekali jumlahnya. Jadi tidak mungkin pengawasan dapat dilakukan secara maksimal..." 
Berdasarkan ulasan di atas, nampak jelas bahwa minimnya jumlah SDM menjadi alasan utama terkendalanya program pengawasan terhadap BMT. Hal ini sesuai dengan penelitian Pratiwi \& Janah (2015), yang menyatakan bahwa keterbatasan SDM menjadi salah satu penyebab kegagalan BMT. Kondisi tersebut menjadi salah satu penyebab tidak tertanganinya masalah BMT PSU sejak dini, sehingga mengakibatkan kebangkrutan tidak terhindarkan. Permasalahan terkait pengawasan dan pembinaan oleh pihak Dinas Koperasi dan Usaha Mikro Kota Malang lebih disebabkan oleh rendahnya kuantitas dan kualitas SDM di dinas koperasi, khususnya yang menjabat di bidang pengawasan, sehingga pembinaan dan pengawasan yang selama ini dijalankan oleh pihak Dinas Koperasi dan Usaha Mikro Kota Malang tidak berjalan secara maksimal.

\section{Munculnya Pesaing Baru yang Lebih Kuat}

Munculnya pesaing baru dengan modal yang jauh lebih besar dan manajemen yang lebih profesional seperti bank umum yang membuka unit usaha mikro tentunya menjadi momok tersendiri bagi BMT. Sebut saja Bank Mandiri yang membidik kredit yang telah merealisasikan penyaluran kredit mikro sebesar 85,6 triliun untuk kwartal I tahun 2018 (Pitoko, 2018). Tidak Bank Mandiri, bank-bank lainnya tentu saja tidak mau kalah, misalnya saja, BNI yang pada tahun 2017 lalu, BNI telah menyalurkan kredit mikro sebesar 56,5 triliun (Yudistira, 2018).

Semakin banyaknya bank umum yang membidik usaha sektor mikro, berakibat pada semakin sulitnya posisi BMT, khususnya BMT PSU karena harus bersaing dengan bank-bank yang telah mapan dari segi manajemen dan permodalan. Rasanya sungguh tidak fair, jika BMT yang masih harus merintis dari nol, harus dipaksa bersaing dengan bank-bank yang telah mapan. Menurut Darsono dan Ashari (2005 : 101), kondisi persaingan yang semakin ketat ini menjadi salah satu penyebab kebangkrutan sebuah perusahaan.

Terjunnya perbankan ke sektor mikro yang menimbulkan polemik di kalangan praktisi BMT semakin diperparah dengan tidak adanya pembatasan dari pihak Bank Indonesia terhadap bank-bank yang menggarap sektor mikro tersebut. Alasan yang dipakai oleh pihak BI adalah belum adanya regulasi yang mengatur segmentasi setiap lembaga bank atau nonbank, sehingga pihak Bank Indonesia merasa tidak perlu melarang bank umum untuk membuka unit bisnis di sektor mikro. Semakin menjamurnya bank umum yang membuka layanan bisnis sektor mikro, membuat BMT PSU dan BMT lainnya semakin terjepit ruang geraknya. Nama besar dan trust yang dimiliki oleh bank, cepat atau lambat mulai menggerus dan meneggelamkan BMT sebagai penggerak sektor mikro, sehingga jika hal ini terus dibiarkan, maka bukan tidak mungkin BMT akan tinggal kenangan semata, seperti nasib BMT PSU saat ini yang telah hancur tak bersisa.

Tabel 1. Rangkuman Hasil Pembahasan

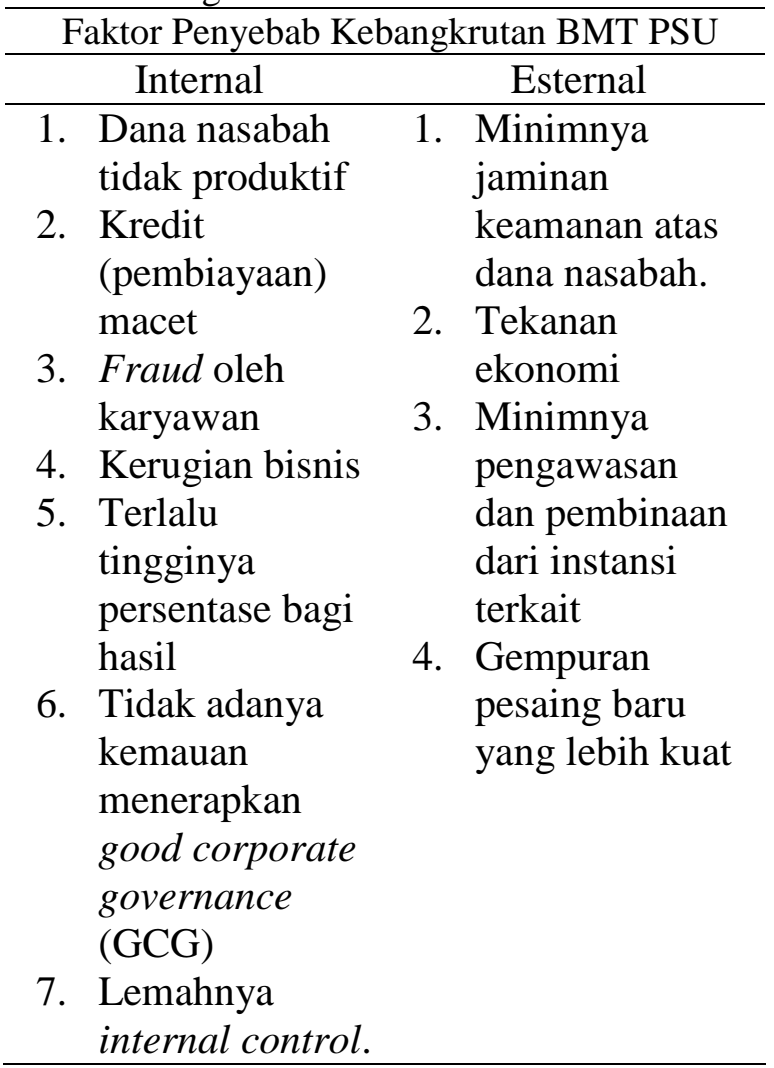

Sumber : data diolah 


\section{Kesimpulan}

Berdasarkan uraian di atas terungkap beberapa fakta mengejutkan yang menjadi alasan di balik kebangkrutan BMT PSU. Adapun alasan dibalik bangkrutnya BMT PSU dikelompokkan menjadi dua faktor internal dan eksternal. Adapun faktor internal yang menyebabkan kebangkrutan BMT PSU yaitu: manajemen dana tidak produktif, kredit (pembiayaan) macet, fraud oleh karyawan, kerugian bisnis, terlalu tingginya persentase bagi hasil, tidak adanya kemauan menerapkan good corporate governance (GCG) dan lemahnya internal control. Selain faktor internal, peneliti juga menemukan faktor ekternal yang menyebabkan kebangkrutan BMT PSU. Adapun faktor eksternal tersebut meliputi: minimnya jaminan keamanan atas dana nasabah, tekanan ekonomi, minimnya pengawasan dan pembinaan dari instansi terkait, serta gempuran pesaing baru yang lebih kuat. Pada akhirnya seluruh temuan terkait faktor penyebab bangkrutnya BMT PSU tersebut diharapkan dapat berguna sebagai informasi bagi pihak terkait dalam penyusunan berbagai strategi untuk memperkuat BMT di masa-masa yang akan datang. Strategi penguatan BMT perlu disusun sedemikian rupa agar musibah yang menimpa BMT PSU tidak terulang kembali pada BMT lainnya.

\section{DAFTAR PUSTAKA}

Al-Qur'an

Ahmed, H. (2002). Financing Micro Enterprises: An Analytical Study of Islamic Microfinance Institutions. Journal of Islamic Economic Studies, Vol.9. Issues 2.

Albrect. W. Steve. (2012). Fraud Examination. Canada: South Western Chengage Learning.

Anoraga., B. (2015). Agency Problem in Financing: The Case of Islamic Coorporation (BMT) in Indonesia. Master Thesis. Islamic Finance and Management at Durham University, United Kingdom.

Bank Indonesia. (2018). BI 7-day(Reverse) Repo Rate. Diakses dari http://www.bi.go.id/id/moneter/bi-7dayRR/data/contents/Default.aspx.

Blanque, P. (2003). Crisis and Fraud. Journal of Financial Regulation and Compliance, Vol.11, No.1,pp. 60-70.

Chowdhury, S. (2006), Creating an Islamic Microfinance Model: The Missing Dimension, Dinar Standard: Business Strategies for the Muslim World, New York, NY

Darsono \& Ashari. (2005). Pedoman Praktis Memahami Laporan Keuangan. Yogyakarta : Andi Yogya.

Djazuli, A., \& Janwari, Y. (2002). LembagaLembaga Perekonomian Umat (Sebuah Pengenalan). Jakarta: Raja Grafindo Persada.

Dorminey, J., Fleming, A.S., Kranacher, M.J., \& Riley, R.A.Jr. (2012). The Evolution of Fraud Theory. American Accounting Association, Vol.27, No.2, pp. 555-579.

FCGI. (2001). Peranan Dewan Komisaris dan Komite Audit dalam pelaksanaan Corporate Governance. Seri Tata Kelola Perusahaan. Jilid II. Edisi ke - 2 Jakarta.

Ganesan, S. (1994). Determinants of Longterm Orientation in BuyerSellerRelationship. Journal Marketing, Vol.58, pp. 1-19.

Ghofur, A. (2016). Konsep Riba dalam AlQur'an. ECONOMICA, Vol.7, No.1, pp. 1-26.

Ghofur, M. (2007). Potret Perbankan Syariah Indonesia Terkini. Yogyakarta: Biruni Press.

Hadiwiyono, P.S., \& Panjaitan, T.W.S. (2013). Perancangan Standard Operating Procedure (SOP) Departemen Human Resources (HR) Di PT. X. Jurnal Titra, Vol.1, No.2, pp. 227-232.

Harling, K. (2002). An Overview of Case Study. This Paper supports a similiarly titled discussion that Harling Conducted at the learning workshop," Case Studies: Their Future Role in Agricultural and Resource Economics, "The American Agricultural Economics Association, Long Beach, California, July 27, 2002.

Huang, X., Iun, J., Liu, A., \& Gong, Y. (2009). Does Partisipatif Leadership 
Behaviour on Psycological Empowerment and Organizational Commitment in Chinese State Owned Enterprise: The Moderating Role of Organizational Tenure. Asia Pasific J.Manage, Vol.2, No.3, pp. 345-367.

Ikopin. (2015). UU Republik Indonesia No.

25 tahunh 1992 tentang Perkoperasian. Diambil http://www.ikopin.ac.id/wpcontent/uploads/2015/07/UU-Nomor25-tahun-1992-tentang-Perkoperasian.

Janwari, Y. (2015). Lembaga Keuangan Syariah. Bandung: PT.Remaja Rosdakarya Offset.

Juwaini, A., \& Mintarti, N. (2010). BMT (Baitulmaal wa Tamwil) Islamic Micro Financial Services for The Poor. ISO/Copolco Workshop Bali, Bali.

Kasmir. (2012). Manajemen Perbankan. Jakarta: PT. Raja Grafindo.

Komite Nasional Kebijakan Governance. (2006). Pedoman Umum Good Corpotrate Governance Indonesia. Jakarta.

Kusmiyati, A.N.S. (2007). Risiko Akad dalam Pembiayaan Murabahah pada BMT di Yogyakarta (dari Teori ke Terapan). La_Riba, Vol1, No.1, pp. 2741.

Mardian, S. (2015). Tingkat Kepatuhan Syariah di Lembaga Keuangan Syariah. Jurnal Akuntansi dan Keuangan Islam, Vol.3, No.1, pp. 57-68.

Mulyadi. (2001). Sistem Akuntansi. Jakarta: Salemba Empat.

Nawatmi, S. (2010). Pandangan Islam Terhadap Bunga. Dinamika Keuangan dan Perbankan, Vol.2, No.1. pp. 38-46.

Pitoko, R.A. (2018). Bank Mandiri Kejar Target Kredit Mikro Tumbuh 32 Persen pada 2018. Diambil dari https://ekonomi.kompas.com/read/2018/ 05/07/223905026/bank-mandiri-kejartarget-kredit-mikro-tumbuh-32-persenpada-2018

Prastiawati, F., \& Darma, E.S. (2016). Peran Pembiayaan Baitul Maal Wat Tamwil Terhadap Perkembangan Usaha dan Peningkatan Kesejahteraan Anggotanya dari sektor Mikro Pedagang Pasar Tradisional. Jurnal Akuntansi dan Investasi, Vol.17, No.2, pp. 197-208.

Pratiwi, E.K., \& Janah, N. (2015). Inventarisasi Permasalahan Industri Keuangan Mikro Syariah (Studi Pada BMT di Kota dan Kabupaten Magelang). Cakrawala, Vol.10, No.1, pp. 23-30.

Purwanto, G.K \& Mustamu, R.H. (2013). Studi Deskriptif Penerapan PrinsipPrinsip Good Corporate Governance Pada Perusahaan Keluarga Di Bidang Manufaktur Kayu. Agora, Vol.1, No.1, pp. 1-12.

Qodin, A.N. (2015). Analisis Penyelesaian Pembiayaan KJKS BMT Fastabiq Pati. Iqtishadia, Vol.8, No.2, pp. 305-328.

Rahim, A., \& Rahman, A. (2010). Islamic Microfinance: An Ethical Alternative to Poverty Alleviation. Humanomics, Vol.26, No.4, pp. 284-295.

Saxton, Todd. (1997). The Effect of Partner and Relationship Characteristic on Alliance Outcomes. Academy of Management Journal, Vol.4. No.2, pp. 443-461.

Schermerhorn. (2002). Pengawasan dalam Manjemen. Jakarta: Bina Aksara.

Scott, W. R. (2006). Financial Accounting Theory. 4th Edition. Pearson Education. Canada.

Solomon, J. (2007). Corporate Governance and Accountability. United Kingdom: John Wiley\& Sons Ltd. Sugiyono.

Soeyitno, A.H. (2013). Hubungan Antara Persepsi KaryAwan terhadap Gaya Kepemimpinan Partisipatif Atasan dengan Kinerja Karyawan di RS. Muji Rahayu Surabaya. Jurnal Psikologi Industri dan Organisasi, Vol.2, No.2, pp. 111-117.

Steger., Urich., \& Wolfgang, A. (2008). Corporate Governance: How to Add Value. John Wiley \& Sons, Ltd.

Stoner, Freeman \& Gilbert. (1995). Pengantar Bisnis. Yogyakarta: Graha Ilmu.

Tambunan, R.M. (2013). Pedoman Penyusunan Standard Operating Procedures (SOP). Jakarta: Maiestas Publishing. 
Tjondro, D., \& Wilopo, R. (2011). Pengaruh Good Corporate Governance (GCG) Terhadap Profitabilitas dan Kinerja Saham Perusahaan Perbankan yang Tercatat di Bursa Efek Indonesia. Journal of Business and Banking, Vol.1, No.1, pp. 1-14.

Ulum, F. (2014). “Optimalisasi Intermediasi dan Pembiayaan BMT Menuju Pemberdayaan Ekonomi Masyarakat". Jurnal Studi Keislaman ISLAMICA, Vol.9, No.1, pp. 161-192.

Umar, D. (2017, Mei 31). Nasabah BMT PSU Tagih 17 M. Radar Malang. Diambil dari http://www.radarmalang.id/nasabahbmt-psu-tagih-rp-17-m/

Wardayati, S.M. (2001). Implikasi Shariah Governance terhadap Reputasi dan Kepercayaan Bank Syariah. Walisongo, Vol.1, No.1, pp. 1-24.

Wardiwiyono, S. (2012). Internal Control System for Islamic Micro Finance: An Exploratory Study of Baitul Maal wat Tamwil in the City of Yogyakarta Indonesia. International Journal of Islamic and Middle Eastern Financing and Management, Vol.5, No.4, pp. 340352.

Watson, D.M. (2003). Cultural Dynamics of Corporate Fraud. Cross Cultural Management: An International Journal, Vol.10. No.1, pp. 40-54.

Wijayanto, A., Rahmawati., \& Suparno, Y. (2007) Pengaruh Asimetri Informasi Terhadap Hubungan Antara Penerapan Sistem Perdagangan Dua Papan Di Bursa Efek Jakarta Dan Lndikasi Manajemen Laba Pada Perusahaan Perbankan. Jurnal Bisnis dan Akuntansi, Vol.9, No.2, pp. $165-175$.

Wulandari, P., Kassim, S., Sulung, L.A.K., \& Putri, N.I.S. (2016). Unique Aspects of
The Islamic Microfinance Financing Process: Experience of Baitul Maal Wa Tamwil in Indonesia. Humanomics, Vol.32, No.3, pp. 230-247.

Wulandari, P., \& Kassim, S. (2016). Issues and Challenges in Financing The Poor: Case of Baitul Maal Wa Tamwil in Indonesia. International Journal of Bank Marketing, Vol.34, No.2, pp. 216-234.

Yin, R. K. (2013). Studi Kasus: Desain dan Metode. Jakarta: Rajawali Pers.

Yudistira, G. (2018). BNI Proyeksikan Kredit Usaha Kecil Masih Akan Tumbuh di 2018. Diambil dari https://keuangan.kontan.co.id/news/bniproyeksikan-kredit-mikro-masih-akantumbuh-di-2018

Yuliningrum, H. (2012). Mengukur Kinerja Operasional BMT Pada Tahun 2010 Ditinjau dari Segi Efisiensi dengan Data Envelopment Analysis (DEA) (Studi Kasus BMT si Kota Semarang). ECONOMICA. Vol.2, No.2, pp. 111-128. Yustiningarti, N.D., \& Asyik, N.F. (2017). Pengaruh Asimetri Informasi, Mekanisme Corporate Governance Dan Kompensasi Bonus Terhadap Manajemen Laba. Jurnal Ilmu dan Riset Akuntansi, Vol.6, No.9, pp. 1-17.

Zarkasyi, W. (2008). Good Corporate Governance Pada Badan Usaha Manufaktur, Perbankan, Dan Jasa Keuangan Lainnya. Bandung: Penerbit Alfabeta. 